\section{The Life and Work of Professor J.W. Gregory FRS (1864-1932)}

\section{By Bernard E. Leake}

Geological Society of London,

Memoir No. 34, 2011

Bernard Leake was for many years professor of geology at Glasgow University. In his fine biography - a large and weighty tome - he details the extraordinary career of one of his most notable predecessors, John W. Gregory. Perhaps writing the book can be thought of as an act of institutional piety, but one from which we can all benefit: Gregory was a man who inspired; and his light will now shine even more brightly.

Gregory came from a modest London family. Though small of stature and retiring disposition he was a person of remarkably robust character, as was his sister: young Gregory (11 1 1/2) and Eleanor (9 1/2) walked $55 \mathrm{~km}$ through the night when, after an unaccompanied visit to the seaside, their intended return transport was found to be unavailable. And later we learn that his usual walking speed was $8 \mathrm{~km}$ per hour.

Gregory studied science subjects at Birkbeck College, London, in evening classes while working for a wool company during the day. Soon he was associating with geologists and writing popular articles. His scientific career was launched when he obtained an appointment as an assistant at the British Museum, Natural History, where he worked chiefly on corals and bryozoans.

Then came two opportunities for expeditions in East Africa. The first (189293) was funded by the British Government for 'geopolitical' purposes but was incompetently led by a military officer and was aborted. The second (1893) was under Gregory's leadership and achieved much in the 'wilds' of Kenya, including his recognition of the continent's 'Great Rift Valley' - despite his group having to evade hostile Africans. It was partly financed out of Gregory's own pocket, but used stores abandoned by the preceding expedition. $\mathrm{He}$ proceeded despite his suffering from malaria at the time.

The African work was reconnaissance exploration and survey but it was carried through with great success and yielded important results. Thereafter Gregory undertook extensive travels in many parts of the world, including the 'dead heart' of Australia (in the summer!), Spitzbergen, Tibet, the Americas, much of Europe, and of course Britain. Eventually he died at the age of 68 by drowning in a gorge in Peru during an expedition that had crossed the Andes and was trying to get to the east by riverboats.

In 1900, Gregory was appointed to the chair of geology at Melbourne University and he and his family moved to the Antipodes. The University was in financial straits and the facilities were rudimentary. Nevertheless, with his characteristic energy Gregory soon had things moving; and he also assumed leadership of the Victorian Survey and succeeded in resuscitating that also. The Melbourne authorities had mining in mind as the focus of interest of the geology department; so Gregory quickly shifted his focus from palaeontology to mining geology. (He had in fact studied metallurgy, among other subjects, at Birkbeck.) Leake believes that Gregory would have been happy to stay in Australia (and he retained links there for the rest of his life), but his wife preferred to be in Britain and so he obtained the chair at Glasgow, where again he had to resuscitate a department. He did this so successfully that in time Glasgow became the largest department in Britain. But his travels did not cease: he visited the Caribbean, South Georgia, Burma, much of Europe, India, Tibet, Australia again, Angola, the Americas, Scandinavia and other parts of Europe. . , and of course much of Britain.

Gregory was, as Leake puts it, a workaholic. He authored or co-authored 33 books (including textbooks) and some 313 single-authored papers and reviews, and 32 co-authored items, as well as numerous popular articles. He was on numerous committees, including one that reviewed the state of Indian universities. He was elected FRS and was twice President of the Geological Society (making notable Presidential Addresses). He was renowned as a leader of field excursions and was a highly successful teacher and lecturer, though it seems that he had difficulty in controlling large first-year undergraduate courses (which paradox is not explained by Leake). $\mathrm{He}$ willingly 'got up' new fields as needed. But perhaps he spread himself too thinly and he was not a notable theorist, despite being geologically omniscient! He was, like many, a devotee of Suess, but also accepted and upheld W. L. Green's (1875) 'tetrahedral' theory of the Earth's distribution of oceans and continents, according to which large landmasses are 'complemented' by large areas of water at the opposite sides of the globe. The tetrahedral form of the Earth supposedly arose because the tetrahedron is the regular solid with the largest surface area for a given volume; and therefore it might be expected that a cooling and shrinking spherical Earth would produce a form on solidifying that was somewhat tetrahedral.

The corollary of this hypothesis was that the areas of land and ocean would be approximately constant, though with the depth of the oceans varying somewhat over time, so that plant or animal migrations across areas that are presently oceans could occur. So Gregory was a 'fixist' of a kind, and opposed the drift theory espoused, for example by his colleague the younger Edinburgh geology professor Arthur Holmes. Gregory's opposition did not help the mobilist cause. But perhaps having a bet both ways, he wrote in the Van Waterschoot van der Graacht 1926 Symposium volume on the theory of continental drift that had "no a priori objection to the drift hypothesis" (p. 94).

Gregory had unorthodox ideas about the formation of eskers and drumlins and also the origin of fiords, which, he thought, originated as a result of some kind of crustal fracture. On the latter point he was ahead of his time. On the former, his ideas have not been accepted. Nevertheless, he did a good deal of geomorphological and Quaternary work

One might have thought that, residing in Glasgow, and leading numerous student excursions into Scotland, Gregory would have become the authority on Scottish geology. But Leake describes Gregory's swansong, Dalradian Geology (1931), as a "complete disaster". Gregory ignored the then new criteria of graded bedding and cross bedding to determine 'way-upness' that had been proposed by E. B. Bailey (who succeeded him in the Glasgow chair in 1929 and later became Director of the British Survey). The Dalradian rocks of Scotland are an exceedingly complex set of mostly metamorphic rocks of Neoproterozoic age, extending into the Lower Palaeozoic and lying between the Great Glen Fault and the Highland Boundary Fault, all much deformed by the so-called Grampian Orogeny. Gregory imagined a relatively simple structure, with generally north-dipping rocks; and he ignored repetitions of strata due to strike-slip faulting. The mysteries of the Dalradian sequence could only be fathomed 
by close mapping of the metamorphic rocks; and Gregory did not do this.

Yet Gregory did not hesitate to offer worldwide correlations for the Scottish successions. This, I suggest, exemplifies the dangers of thinking or working on too grand a scale. Gregory did rather little map-work in his career, and especially not for metamorphic rocks. The Dalradians were almost on his doorstep in Glasgow, and offered more than enough interest and problems to satisfy anyone. But in 1931 Gregory's aging eyes were seemingly set on further reconnaissance survey work, this time in South America, and he did not accomplish what he might have done by painstaking work in the Scottish metamorphics. After Gregory's death, Bailey drew attention to his shortcomings on Dalradian geology.

Having done so much travelling in remote parts of the world, Gregory encountered many non-Europeans, established cordial relations in most cases, and became generally interested in anthropology and human migration. (He also did some archaeological work in Africa.) However, he left Australia as a supporter of the now notorious 'White Australia' policy and might today be regarded as a racist (though he spoke well of the Aboriginal guides he used in Australia). Even so, he was evidently a most agreeable man with a wide circle of friends and acquaintances. Also, as Leake shows, he had a considerable influence on the teaching of geology in Britain, manifesting a kindly respect for his students. On the other hand, he appears to have been tenacious in defending his views - and well able to do so on the basis of his vast first-hand empirical knowledge and his immense knowledge of the literature.

Besides giving a comprehensive account of Gregory's extraordinary career as a geologist Leake also gives interesting and quite detailed accounts of his personal life and the social conventions of a family of a distinguished and influential professor for the period in question. They were rather formal and highly 'respectable', but also endearing.

Gregory's travel books show him to have been extraordinary robust and resilient, and an excellent organiser, apparently getting on well with his various co-expeditionists. One would think from his accounts that he spent all his time simply coping with the rigours of travel, but we also see that he was constantly collecting specimens and making and recording observations. The lists of references to the areas he visited show that he was fully cognisant of previous relevant work. By the time of his explorations, there were some travel advantages such as railroads and regular shipping, but not air travel of course. A lot of his writing must have been done aboard ship or on trains; but it appears that at home a great deal of his writing and thinking was done in the early hours of the morning. He was generally active for twenty hours a day.

Bernard Leake's task must have been a massive one as his subject was so 'large'. But he appears to have examined and digested all likely sources, both in archives and libraries. The book could have become too 'heavy' (and it is indeed a weighty as well as a large tome), but the chapters are relatively short, and each deals with a discrete aspect of Gregory's work. So one does not have to read all at one sitting.

I have, fairly recently, been examining the general issue of geologists' biographies or autobiographies and tabulating a large mass of information (derived especially from William Sarjeant's monumental bibliographical study Geologists and the History of Geology, 10 volumes). Certain patterns have begun to emerge. The literature in English, German, and French (in that order) far exceeds that in other languages. Naturally, one is more likely to have a biography if one is a major figure or has made some really major contribution to geoscience. (Yet some major figures like Lapworth, or Bailey for that matter, lack biographies.) If a geologist makes a particularly notable contribution to an institution, then an author from that institution may be more likely to honour him with a biography. People who have special fame in fields other than geology (e.g. Cuvier, Darwin, Teilhard de Chardin, von Humboldt, Linnaeus, Kelvin) receive a great deal of biographical attention. And being a woman helps! But more than anything, being a traveller encourages the writing of both biographies and autobiographies. (And, the evidence reveals, Muslim countries do not produce works of this genre; and India and Africa have had little to offer.) To a large extent, in Gregory's day geology was strongly associated with colonial and imperial activities. Indeed, for the cover illustration of his book Leake uses a global map showing (in red!) the areas that, in Gregory's time, formed parts of the British Empire. And the book reveals that there was formerly a significant link between geology and empire.

So on many counts it is unsurprising that Gregory should receive a biography and that Leake should be the person to have written it. He has done so with enormous diligence and skill, and the result is not only a testimony to Gregory but to the devoted work of his biographer. And for the geologist reader, Gregory should serve as an inspiration. Also the book displays what was known about geological matters in the decades 1890-1930. One can also learn a good deal about geography and social history from it. Thoroughly recommended!

\section{David Oldroyd}

The University of New South Wales

Sydney NSW 2052, Australia

E: doldroyd@bigpond.com 